\title{
Study on Party Construction for Students in Southwest Petroleum University
}

\author{
Long Guo \\ Organization Department, Southwest Petroleum University, Chengdu, China \\ Email: guolong2016@163.com
}

Received 7 March 2016; accepted 26 April 2016; published 29 April 2016

Copyright (C) 2016 by author and Scientific Research Publishing Inc.

This work is licensed under the Creative Commons Attribution International License (CC BY). http://creativecommons.org/licenses/by/4.0/

(c) (i) Open Access

\begin{abstract}
To strengthen and improve college students' party construction in the new period is very important, and it has a great significance. The university is the cradle of cultivating a new generation of the motherland, carrying the hope of the future. Strengthening the university student party construction work, and training more excellent party members have very important role in realizing the great rejuvenation of the Chinese nation. The university student party building work has made some achievements in recent years, but it still exists some problems which cannot be ignored. This paper makes a deep study on the new situation and new problems about the university student party building work, and finds out some measures and countermeasures of some new methods for university students to provide the theoretical support for the work of Party building.
\end{abstract}

\section{Keywords}

College Students, Party Construction, Southwest Petroleum University, New Methods

\section{Introduction}

To strengthen and improve college students' party construction in the new period is very important, and it has a great significance. The university is the cradle of cultivating a new generation of the motherland, carrying the hope of the future (Ashton, 2000). Strengthening the university student party construction work, and training more excellent party members have very important role in realizing the great rejuvenation of the Chinese nation. The university student party building work has made some achievements in recent years, but it still exists some problems which cannot be ignored. This paper makes a deep study on the new situation and new problems about the university student party building work, and finds out some measures and countermeasures of some new methods for university students to provide the theoretical support for the work of Party building.

With enrollment expansion of colleges and universities reform and situation of the development of social economy, college students' party construction has entered a new period. As an important part of the party con- 
struction of university student party construction work, we must dare to face it, but we also must be good at facing the new situation and new problems. We must try to cope with the complexity of the CPC party construction of university students under the new period, and create a new situation of university student party construction work in time. Through studying this topic and grasping the new trends of new problems, we should change the "problems" into "opportunity", and carry out the work of the party construction of university students (Carter, Bishop, \& Kravits, 2000). Therefore, college students’ party construction method research has very important theoretical significance.

\section{The Problems of College Students' Party-Building Work in Southwest Petroleum University}

In the new period, the development of college students' party building has made a certain progress, but at the same time, we must clearly see that college students' party building in the new period still exist many new problems in the process of dealing with old problems (Chapell, Blanding, Silverstein, Takahashi, Newman, Gubi, \& McCann, 2005).

(1) The motives of college students to join the party have deviation (Wu, 2002)

With the strengthening of party building work and ideological and political education in Colleges and universities, more and more students are applying to join the party. The motivation of most students to join the party is basically correct, and most students have a more profound understanding of the party, can really join the party in mind. But some students' motives to join the party has deviation, and some students have the following points: First, some students have no faith to join the party; second, some students out of a sense of pride and honor to join the party (Mo \& Zhang, 2007). They know the Communist Party of China is a sacred and great party; to join the Communist Party is a great honor; third, some students see others write applications, they do the same, but do not know the true nature of Communist Party member; fourth, some students to join the party just for looking for a job. Now, when a college student is looking for a job, the employer first asks if he is a member of the Communist Party. Party members are the first choice of employers, which undoubtedly increased the enthusiasm of college students to join the party. In order to find a job, some students are eager to join the party.

(2) Pay attention to training before joining the party, despise education after joining the party

"Pay attention to training before joining the party, despise education after joining the party" is still the problems in the work of party building for college students. With the expansion of the quantity of student party members, the difficulty of college party workers of student management and education of the party members is expanding. Some college party affairs workers to join the party activists attach great importance to the training and education work of party school training examination, tissue constitution study, join party practice... However, lack of further education of card-carrying party members, blindly expanding branch, ignore to the card-carrying party member's education. Such examples can be seen everywhere, before some students officially joined the party, no matter in life or study attitude are required to be positive. After joining the party, the requirements for the card-carrying party members are loose, which will have a bad effect on most students (Chou \& Wang, 2000).

(3) Can not accurately grasp the standard of joining the party

There are some colleges and universities for students to join the party's qualification examination is not strict. On the one hand, a small number of student party branches in the process of the development of student party members only pay attention to speed and quantity. Qualification examination becomes a mere formality, and even have unfair phenomenon, can not really absorb the outstanding students to the party organization; on the other hand, in some colleges and universities, the standard of party members equivalent to the standard of three-good students. In the process of the development of party members, only pay attention to grades, job performance, lack of the study of political ideology. In the aspect of study and work, have a positive attitude, in the aspect of ideological and political consciousness, have high sense of responsibility, is really a reasonable standard of student party members.

(4) The role of advanced student party members is not obvious

Student party members must have down-to-earth spirit and persistent attitude, set an example for other college students (Demirbas \& Demirkan, 2003). But, in fact, some students, since joined the Communist Party of China, began to relax the demands of their own thoughts, too much to consider individual interests. This is a kind of utilitarian psychology, there is no real ideological to join the party. A lack of understanding of the party's theory and lack of self-discipline, can not be self critical and self reflection in time, this is the problem should be pay 
attention to in the work of our Party.

\section{The Methods about College Students' Party-Building Work}

College students are valuable human resources of the country, the hope of the nation, the motherland's future, shouldering the trust of the people, the history of the responsibility. College education is a significant stage for human development. In the process of the overall development, students' thinking ability is the key to the formation, promotion and development. In the new situation, the importance of College Students' Party-building work is more prominent, combined with the actual situation of the university party-building work, strengthen education and management of student party members, under the new situation to be able to continue to promote and create the university party-building work (Demirbas \& Demirkan, 2007). As a grass-roots party member, especially a grassroots party affairs worker, must change the idea, recognize the significance of the work of party-building in Colleges and universities. Combined with practical work, contribute to college students' party construction work, mainly has the following aspects:

(1) Improve the entrance education, ideological enlightenment of party. Freshmen education is the first lesson of college students after entering the campus. In the process of school education, to highlight the role of guiding the ideological and political education of university students, puts forward the expectations and requirements. Through a series of enlightenment education activities, it arouses students' progressive political enthusiasm.

(2) Grasp the focus, early training and early establishment. Grasp the focus of the part is for the performance of the more prominent students, conscientiously do a good job in the large range of ideological enlightenment education. At the same time, we should pay attention to foster the thought on the basis of good students cadres, three-good students, and actively organize the basic knowledge and theory to guide all the students to study the party. At the same time, organize students to discuss learning content and the exchange of learning experiences, educate and guide them to take the initiative to move closer to the party organization. Early training, and add the party school training to the freshmen entrance education. Encourage the freshman in the first year of college to join the part. Early establishment is to build student party branch as soon as possible.

(3) We must pay attention to the education of the party activists, and establish an effective mechanism and give a full play of the role of party organization in the ideological and political work of the students. (Efklides, Papadaki, Papantoniou, \& Kiosseoglou, 1997). Under the help of party group to build the party group, grasp the purpose of the party-building work, play a more effective role for the party building. In Youth League organizations institutions, secondary school (Department) of the Secretary of the Communist Youth League can be served as branch secretary of college students and make the work content of mutual penetration. In the selection of class cadres, party group secretary to play a role, to strengthen the role of political leadership class work. Guidance program should be strictly controlled to ensure the quality of the party branch. Adhere to strict command system, increase the seriousness and objectivity of the recommendation work.

(4) Give full play to the guiding role model of party members. Give full play to the exemplary role of party members, party members and activists should establish links, through the demonstration and guidance, strengthen the education and training of activists. At the same time, the party branch meeting in time, strengthen the cultivation of party activists and let them to participate in various activities, help them all-round development and progress.

(5) Take various forms and guide party members and party activists to participate in various activities of social practice, and actively guide them to participate in campus cultural activities and the activities of student organizations, training talents in practice.

\section{Conclusion}

In the process of Party construction work of college students in the new period, we must learn something about the thought construction, organization construction, style construction, system construction, construction of a clean and honest government positive development, and actively research, which can answer those questions, solve all the problems, and help to build the scientific development concept as a guide open the new situation of the party construction work of college students in the era of innovation (Stephens \& Graig, 1990). In a word, in the process of Party construction for students in Southwest Petroleum University, the work should be done which is combination with the times, and vigorously promote the truth-seeking and pioneering spirit, constantly explore and constantly improve, constantly enrich and deepen the development of Party building work. 


\section{References}

Ashton, P. (2000). Collective Action for Design Learning-Social Interaction Analysis in the Design School Studio. In S. Scrivener, L. Ball, \& A. Woodcock (Eds.), Collaborative Design (pp. 513-524). London: Springer. http://dx.doi.org/10.1007/978-1-4471-0779-8_48

Carter, C., Bishop, J., \& Kravits, S. L. (2000). Keys to Effective Learning (2nd ed.). Upper Saddle River, NJ: Prentice Hall.

Chapell, M. S., Blanding, Z. B., Silverstein, M. E., Takahashi, M., Newman, B., Gubi, A., \& McCann, N. (2005). Test Anxiety and Academic Performance in Undergraduate and Graduate Students. Journal of Educational Psychology, 97, 268-274. http://dx.doi.org/10.1037/0022-0663.97.2.268

Chou, H. W., \& Wang, T. B. (2000). The Influence of Learning Style and Training Method on Self-Efficacy and Learning Performance in WWW Homepage Design Training. International Journal of Information Management, 20, 455-472. http://dx.doi.org/10.1016/S0268-4012(00)00040-2

Demirbas, O. O., \& Demirkan, H. (2003). Focus on Architectural Design Process through Learning Styles. Design Studies, 24, 437-456. http://dx.doi.org/10.1016/S0142-694X(03)00013-9

Demirbas, O. O., \& Demirkan, H. (2007). Learning Styles of Design Students and the Relationship of Academic Performance and Gender in Design Education. Learning and Instruction, 17, 345-359. http://dx.doi.org/10.1016/j.learninstruc.2007.02.007

Efklides, A., Papadaki, M., Papantoniou, G., \& Kiosseoglou, G. (1997). Effects of Cognitive Ability and Affect on School Mathematics Performance and Feelings of Difficulty. The American Journal of Psychology, 110, 225-258. http://dx.doi.org/10.2307/1423716

Mo, Y. R., \& Zhang, Q. (2007). Study on Influence of Conformity on College Students' Attitude to Sports. Science and Technology Information, 35, 558.

Stephens, T., \& Graig, C. L. (1990). The Well-Being of the Canadians: Highlights of the 1988 Campbell's Survey. Ottawa: Canadian Fitness and Lifestyle Research Institute.

Wu, L. (2002). Exploration on Conformity among Chinese College Students. Journal of Henan Education College, 2, 35-36. 